Article

\title{
Case Selection in the Russian Constitutional Court: The Role of Legal Assistants
}

\author{
Aryna Dzmitryieva
}

The Institute for the Rule of Law, European University in St. Petersburg, 3A Gagarinskaya Street, 191187 St. Petersburg, Russia; admitrieva@eu.spb.ru

Received: 17 July 2017; Accepted: 8 August 2017; Published: 15 August 2017

\begin{abstract}
Constitutional courts throughout the world are highly selective in forming their agenda. Scholars who have studied the setting of agenda have not reached agreement on the role of legal clerks in this process. This article focuses on the role of the Secretariat of the Russian Constitutional Court in the case selection process. The Russian Constitutional Court receives about twenty thousand petitions annually. Nevertheless, only dozens of them are decided on their merits by judges. Through the description of the case movement process we show that the Secretariat does have at least moderate influence on case selection. Using data received from observation and interviews with the Court's staff and judges, we find that legal assistants' decision on whether to promote a case to judges is based on different logics of decision making. First, they are bound by legal requirements. However, bureaucratic logic and the logic of appropriateness can also influence the amount of incentives to promote cases to judges.
\end{abstract}

Keywords: constitutional courts; case selection; law clerks

\section{Introduction}

The role of the Constitutional Court in present day political life in Russia is quite ambivalent. Lawyers and the general public often accuse the Court of not being politically active nor independent enough, and of making decisions that preserve the political status-quo (Koroteev and Golubok 2007; Thorson 2012). However, ordinary citizens often see a complaint to the Constitutional Court of the Russian Federation as the last opportunity for a just resolution of any injustice they may have encountered during previous stages of the litigation process. While hesitant in dealing with public law issues, it seems that the Court proceeds with much more confidence when it comes to cases involving the protection of individual rights. Thus, its agenda is constituted mainly of citizens' complaints.

In recent years, citizens have submitted about twenty thousand petitions annually to the Constitutional Court of the Russian Federation (Table 1). However, about ninety percent of them were declined by the Secretariat of the Constitutional Court because they were found to be non-compliant with the requirement of the Law on the Constitutional Court (LCC). Only a few petitions received the consideration of a judge. Upon judicial review, complaints might receive one of the following two types of decisions: (a) rulings or decisions on the merits (in Russian, "Postanovlenie") or (b) a decision to dismiss the complaint (in Russian, "Opredelenie"). Both numbers are very small compared to the total number of petitions received by the Court. For instance, in 2012, the Court issued only 34 rulings of the 18,745 petitions received, meaning that $99.9 \%$ of the petitions were dismissed by judges or found non-compliant and filtered out by the Secretariat. 
Table 1. The numbers of petitions received and considered by the Court in 2000-2012.

\begin{tabular}{cccc}
\hline Year & Total Number of Petitions & Rulings-Decisions on the Merits & Orders to Dismiss \\
\hline 2000 & 10,983 & 15 & 296 \\
2001 & 12,296 & 17 & 309 \\
2002 & 14,472 & 17 & 300 \\
2003 & 15,668 & 20 & 513 \\
2004 & 15,561 & 19 & 473 \\
2005 & 14,943 & 14 & 536 \\
2006 & 14,989 & 10 & 635 \\
2007 & 16,612 & 14 & 946 \\
2008 & 16,592 & 11 & 997 \\
2009 & 20,629 & 20 & 1676 \\
2010 & 18,214 & 22 & 1722 \\
2011 & 19,142 & 30 & 1864 \\
2012 & 18,745 & 34 & 2557 \\
\hline
\end{tabular}

From the numbers in Table 1, it is also evident that the transfer of the Court from Moscow to St. Petersburg in $2008^{1}$ affected all aspects of the Court's workload. First, in 2009, there was a significant rise in the number of the petitions submitted. Accordingly, the number of decisions made by the Court has also increased. More important to the present study is the fact that the patterns of case selection have also changed.

Figure 1 illustrates this statement. There was a sharp rise observed in the number of petitions received by the Court in 2009 and in the years that followed as compared to the immediate few years before that. The line graph illustrates the number of petitions found to be non-compliant. The percentage of petitions found to be non-compliant with the LCC was relatively stable in the beginning of the 2000s, but after the transfer it has dropped from $94 \%$, in the years before the transfer, to $86 \%$ in just the last year.

The decision of non-compliance with regards to a petition is made by the Secretariat and, therefore, the above-mentioned changes to the Secretariat's conduct raise several questions. What are the main reasons explaining this change of pattern in case selection? Is it the effect of higher judicial activity? Or is it the effect of the almost total replacement of legal assistants that took place as a result of the transfer of the Court from Moscow to St. Petersburg?

With the consistent growth of the number of petitions, neither the number of judges, nor the size of the Court's clerkship are growing. Therefore, the question of how the Court selects complaints to be considered, or in other words, how it makes "the decision to decide" (Perry 1991; Provine 1980) becomes important to the litigants.

The case selection process, thus, becomes an extremely important part of the decision-making process. However, the Russian Constitutional Court (RCC) is very discrete in selecting cases for consideration (Epstein et al. 2001). Within the Court, a specific entity-the Secretariat-plays a crucial role in deciding which cases will proceed to the judges and which cases will be rejected. In fact, one of the biggest public complaints against the RCC is that the Court's Secretariat rejects the vast majority of petitions (Avtonomov 2009; Blokhin 2012; Nastashkin 2002).

Scholarship in the area of law and society often lacks "systematic examination of how legal clerks participate in the decision making" (Baum 1999). The RCC is not an exception to this trend. The common model of the decision making process at the Constitutional Court assumes that policy is created in the process of a strategic interaction between the Constitutional Court and the elected bodies-President and Parliament. The Constitutional Court decides whether to take a policy-relevant case and the other actors-namely the President and Parliament-decide whether to accept, modify, or disregard the decision of the Constitutional Court (Epstein et al. 2001). However, this model ignores the importance of the case selection process itself.

1 The transfer of the Constitutional Court from Moscow to St. Petersburg was the first stage of the project of the transfer of all Russian highest courts to St. Petersburg which has not yet been fully implemented. 


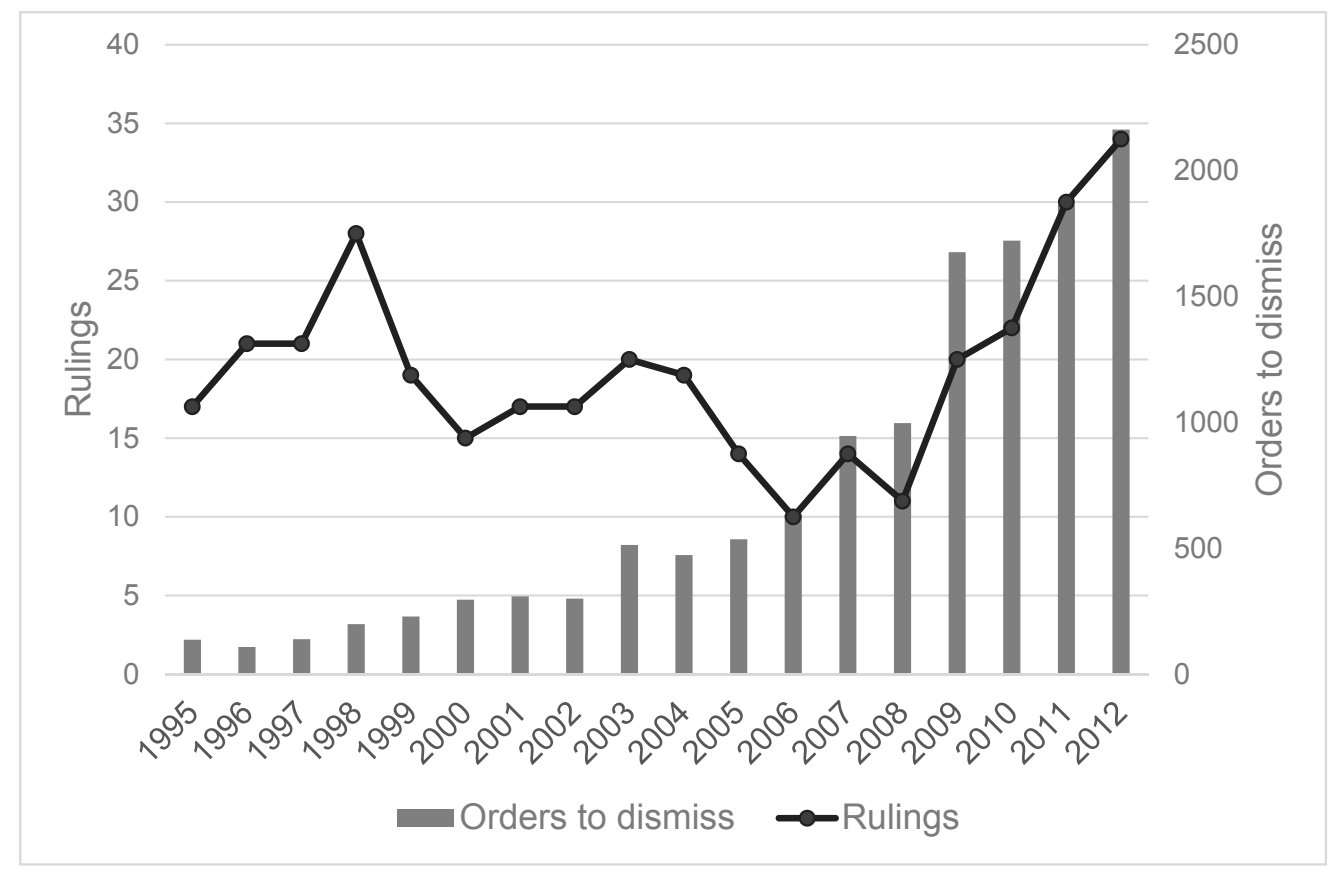

Figure 1. Rulings and orders to dismiss, 1995-2011.

While the participation of law clerks in the case selection process is of great significance, it is difficult to estimate their influence on that process due to the secrecy and lack of understanding surrounding the procedure. Our understanding of the role of the law clerk in the judicial decision making process has been greatly strengthened by the seminal works of Provine (1980) and Perry (1991), as well as recent studies of the clerkship of the U.S. Supreme Court (Peppers 2006; Ward and Weiden 2006), an investigation of appellate and state high courts (Swanson and Wasby 2008; Wasby 2012), a short outline of clerkship at the German Constitutional Court (Massing 2002), and a comparative study of Referendaires at the European Court of Justice and law clerks at the U.S. Supreme Court by Kenney (Kenney 2000). The goal of this paper is, therefore, to contribute to research on the decision making process by exploring the work of the Constitutional Court of the Russian Federation with a specific focus on the case selection process.

My argument will proceed as follows. First, I will describe the procedure through which an average petition goes. An examination of the various stages of a petition will shed light on how the Court manages its internal regulations. By introducing descriptive statistics concerning changes in the proceedings of petitions within the Court, I will illustrate the changing nature of the petition procedure.

Then, I will explain the case selection process in the Court. The discussion of this process will be analysed within the framework of institutional theory (DiMaggio and Powell 1991; Olsen and March 2006; Zucker 1987). I argue that cases are selected with a combination of several factors in mind, namely: the requirements prescribed by law (legalistic assumption), the self-interest of legal assistants which lead to a high degree of discretion in the process of case selection (discretional assumption), and the structural pressure of the bureaucratic institutes (managerial assumption). The language of institutional theory will facilitate placing these empirical findings into the theoretical framework. Through the application of these models, I argue that there is a latent tension between the Secretariat and the Court. I believe that the rising number of managerial procedures serves as a means to channel this latent contradiction to achieve a peaceful resolution. It also leads to a higher bureaucratization of the Court and undermines its political power as a leading representative of the judicial branch of authority.

The paper is based on the results of ten weeks of observational study at the Constitutional Court of the Russian Federation conducted by me and my colleague Ivan Grigoriev in June and 
September-October $2012^{2}$. At the Court we were provided with a personal office, a computer, and were given access to the library. In those ten weeks we interviewed sixteen lawyers of the Secretariat, five judicial legal assistants, seven judges, and five defense attorneys who represented citizens. Interviews lasted 45 to $120 \mathrm{~min}$. and in some cases respondents allowed us to return with additional questions. We also attended public hearings, and could observe the everyday communication of the Court staff occurring in public spaces (library, dining hall and cafeteria). In addition, I use the records of six interviews with present and former judges of the Court which were conducted for another project. I work with 39 interviews in total (six of them off the record). The numbers I use to illustrate my arguments were either received directly from the Court or collected during my research. From the Court's web-site, I also collected the information on the status of all the petitions sent to the Court in 2012. The database was created on 1 March 2013.

\section{The Constitutional Court: An Overview}

Although I approach the Court mainly from ethnographic and sociological perspectives, the political and legal context in which the Court operates should also be considered. The Court must be situated within a political context regardless of which model of constitutional review it draws upon, whether a specialized constitutional court like in most European countries (including Russia) or an ordinary court, which exercises constitutional review along with general appeals like U.S. Supreme Court. The agenda of courts authorized to perform constitutional review in different political systems reflects their political role. For instance, the U.S. Supreme Court was very politically active between 1930 and 1960 (Grossman and Epp 2002). The growth of political activism followed the increased presence of the state in all spheres of everyday life. According to Grossman and Epp (2002), the selectivity of the agenda of the Supreme Court was meant to increase the protection of human rights on the one hand, and to support government participation in economic life on the other. Therefore, a study of the Constitutional Court should take into account its place within a broader system.

The Constitutional Court of the Russian Federation was founded in 1991 during the wave of institutional democratization of the early 1990s. The first Law pertaining to the Constitutional Court of 1991 established that the Court should be composed of fifteen judges. However, in 1991, the Parliament managed to elect only thirteen judges. In January 1992, they considered their first constitutional complaint. Initially the Constitutional Court was intended to be open and accessible to citizens. The Law of 1991 established a broad interpretation of the rules of standing (Gadzhiev 2012) and gave a "broad, non-exhaustive list of Constitutional Court powers to review the constitutionality of all acts, decisions, and actions of federal and regional top government bodies" (Trochev 2008, p. 99). The Court used its power via decisions in which the legal norm could be found unconstitutional and through findings (in Russian, "zakliucheniia") on the constitutionality of a legislative proposal. The founders of the Constitutional Court intended to create an effective tool to help bolster judicial control over executive and legislative branches of power (Trochev 2008; Gadzhiev 2012). While initially labeled as "friendly to the citizens", the Court's high number of rejections has become a source of complaints from citizens today.

The constitutional crisis of $1993^{3}$ resulted in the suspension of the Court's activity and, following that, its reorganization. Under a new federal law pertaining to the Consitutional Court introduced in 1994, the number of judges was increased to nineteen, split between the two chambers. This was done in order to change the alignment of pro-president and opposing judges. Also, the competencies of the Court were narrowed. The Court was no longer permitted to decide cases on its own initiative nor to give judicial review to draft legislation. The changes to the composition of the Court and the narrowing

2 We would like to thank the Court's President Valeri Zorkin for facilitating our research in the Court and the Head of the Secretariat Elena Kravchenko and Deputy Head Vladimir Sivitskii for creating very comfortable conditions for our work. We also cordially thank all our interviewees who generously granted us their time and patiently answered our questions.

3 For more on the constitutional crisis, see (Epstein et al. 2001; Balutenko et al. 1997; Pikhoia 2002). 
of its competencies were designed to prevent a repetition of the conflict that had previously existed between the different branches of power. The Court resumed the delivery of justice in 1995. This second Court has shifted its focus from resolving politically sensitive issues to protecting individual rights and developing generally applicable constitutional principles (Trochev 2008, p. 207; Epstein et al. 2001).

The LCC underwent significant changes in 2001: amendments established new requirements regarding the length of tenure for judges; and the Chief Justice and his deputies are no longer elected by other judges but are appointed by the upper house of Russian parliament (the Council of the Federation). These amendments were largely meant to manipulate the composition of the Court, forcing the two most opposing judges to retire.

\section{Recent Changes}

Two recent events undermined both the everyday work of the RCC and its judicial independence. These two blows were the transfer of the Court from Moscow to St. Petersburg in 2008, and the amendments to the Constitutional Court Act in 2010.

The 2010 amendments to the Constitutional Court Act brought about radical changes in the operation of the Court and narrowed its competencies yet again (Avak'ian 2011; Gadzhiev 2012). Three of these amendments, in particular, had a decidedly strong impact on the case selection process. The first limited the Court's focus explicitly to just those specific complaints that were already decided by ordinary courts in specific cases. It was a significant change that, once again, essentially narrowed the competency of the Court. From 2011 onward, only legislative bodies have been allowed to turn to the Constitutional Court for abstract constitutional review. The legal principle of subsidiarity underlies this amendment. This principle is couched in the multi-level process of judicial decision making and aims to preserve the independence of the ordinary court system (Gadzhiev 2012, p. 12).

The second of these three amendments introduced a written procedure to the consideration of merit. The introduction of the written procedure was a response to the Court's complaint about its high workload (Aranovskii and Kniazev 2012). During a meeting with President Medvedev in December 2010, the judges voiced their wish to introduce amendments that would ease and accelerate a trial when it deals with issues previously solved by the Court. Before the introduction of the amendments to the LCC, rulings were exclusively the result of public hearings and therefore the Court dismissed all complaints that stated questions similar to those already answered or solved in previous hearings. Today the Court has more time and resources to decide on the merits of cases which are not completely new to the Court. Such cases are considered during the plenary session and do not require a call for a public hearing. The second goal of this amendment was to improve the execution of the Court's decisions. There is an extreme tension between the Constitutional Court and other courts, such as the Supreme Court or the Supreme Arbitration Court. These courts regularly disregard the decisions of the Constitutional Court (Trochev 2008, p. 214), to such an extent that the Russian Constitutional Court has lobbied for the introduction of written trial proceedings in order to increase the enforceability of its decisions (Trochev 2008).

The third important amendment to the LCC abolished the two chambers. Instead of two chambers working on two cases in parallel, today, all nineteen judges work on one case at a time. This amendment appears to have made things worse, complicating the Court's work and increasing each judge's individual workload. All judges interviewed mentioned that this amendment was unexpected and had never been discussed inside the court, nor in the legal scholarly community. As the result of the abolition of the two chambers, the average length of trial was increased.

The second event undermining the everyday work of the RCC and its judicial authority was the transfer of the RCC from Moscow to St. Petersburg in 2008 under the alleged guise of growing judicial independence. The President suggested the idea of transferring the Constitutional Court to St. Petersburg in 2006. Initially this idea was met with significant resistance from judges and other lawyers. They viewed this transfer as the exile of an important judicial body out of the capital, and as an expression of contempt for its activity. Their resistance was at first supported by the upper house of 
the Parliament. However, despite the above criticism, the Court ran its last open hearing in Moscow in March 2008 and, in May of the same year, it resumed its activity in St. Petersburg. Even though many had already expected the worst, the transfer caused more harm to the Court, its standing, and its activity than anyone could have foreseen initially. Many highly qualified legal assistants (and especially those recognized as legal scholars) decided to quit their jobs and stay in Moscow rather than follow those positions to St. Petersburg.

These recent shocks emphasized the relative weakness of the Constitutional Court as a part of the wider political system. It is yet unclear whether the RCC possesses enough institutional power to behave independently from the legislative and executive branches. The institutional structure of the judicial system, as well as the legislative and executive authorities that work within it, are bombarded with pressure from the outside, while their foundations are rocked by institutional inconsistency.

Embedded in its institutional setting, the Court is never quite independent nor free to promote a preferential agenda. As an institution, the Court makes its decisions while monitoring the reaction of other entities endowed with political power. The Court's freedom of decision is restricted by the agenda of the other authorities on which the Court depends. The judges are restricted by a sense of propriety of behaviors or a set of motivations considered acceptable under given circumstances (Trochev 2008; Gadzhiev 2012). As Gillman and Clayton point out, the judges' behavior might be motivated by "a sense of duty or obligation about their responsibilities to the law and the Constitution and by a commitment to act as judges rather than as legislators or executives" (Gillman and Clayton 1999, p. 5). However, this assumption works well only in well-established institutional arrangements where there is, for example, a clear separation of the branches of government or an established position for each institutional body in the broad social framework. Alexey Trochev shows in his study of the RCC that the process of judicial institutionalization in Russia has not yet been finished (Trochev 2008).

\section{The Secretariat of the Constitutional Court}

The Constitutional Court of the Russian Federation consists of two rather independent sub-divisions-the Court itself and the Secretariat. The Secretariat of the RCC plays a crucial role in the process of case analysis and selection. The Secretariat was often criticized both inside and outside the court for its broad authority and cumbersome structure (Kudriavtsev 2010). Before the liquidation of the two chambers, some scholars called the Secretariat a third chamber, referring to its significant role in the decision making process (Tuzov 2010).

The legal assistants who form the Secretariat have a permanent work contract and staff turnover is normally very low. There are four legal departments in the Secretariat and a "Correspondence Department" which assesses citizens' petitions, providing legal expertise thereupon. The biggest department is the Department of Private Law, which employs sixteen people. The Department of Public Law and the Department of Criminal Justice employ eleven people each. The Department of Labor Law and Social Development is the smallest one with only ten employees. The staff of the Secretariat is composed mainly of legal academics and legal administrators with work experience in ordinary courts.

However, the transfer of the Court from Moscow to St. Petersburg in 2008 has severely affected the staff of the Secretariat. Around $80 \%$ of the legal personnel were replaced. When asked to evaluate the replacement, Court personnel offered a range of responses that varied from extremely negative to neutral to absolutely positive. For instance, one representative from the Moscow team told us the following in an interview:

...the degree of competence of new legal advisers is in no way lower than it was in Moscow. Of course, it took time for them to adapt and gain work experience but overall the "new blood" brought a new and original vision to issues. 
The four legal departments were all affected by the loss of experienced employees. In fact, immediately after the transfer, some departments were forced to hire recent graduates with no work experience in the legal field. Even when the Court selected the most accomplished graduates, their lack of experience affected the quality of their work:

I had to rewrite, cross out and rewrite every draft of notices and orders. It was a huge workload. Now, four years later, everything has improved and stabilized.

(Interview 4)

These drastic changes in staff recruitment and composition affected all dimensions of the Court's routine.

The authority of the Secretariat to "filter" incoming petitions has never been questioned by critics (Blokhin 2012) nor by the Secretariat staff itself (Sivitskii 2012b). Developing the "filter" metaphor, we can make a distinction between "primary" and "fine" filters. The Correspondence Department acts as a "primary filter". It is supposed to weed out petitions that are considered obviously non-compliant with the Court's legal requirement. The four legal departments work as "fine filters". Here the status of a citizen's petition can be transformed, and then it may (or may not) become a complaint. Therefore, it is important to understand how petitions change their status, how quantity changes into quality, and how the principles of labor division influence the final outcome. In order to address these issues properly, we need to evaluate how assistants influence judicial decision making.

The importance of the role of the Secretariat in the case selection process cannot be overestimated. The judicial outcomes of the Court's decisions are determined by the cases available for consideration. But the availability of cases very much depends on the Secretariat's work.

The Secretariat performs two basic functions. First, it performs judicial analyses of petitions and prepares cases for the judges' considerations on merit. Second, it eliminates petitions in order

to protect the Court from non-compliant petitions, in order for judges not to work on completely irrelevant things.

(Interview 6)

The lacunae in public knowledge of the Secretariat's role in the case selection process can be remedied by studying everyday practices inside the Court at each of its levels: from the Correspondence Department to Statistical Units; from the legal departments to plenary hall oral arguments. Once we understand better the balance of power among these units, we can evaluate the role of the Secretariat in delivering the cases to their final stage: consideration on merit.

\section{The Trajectory of the Petition to the Constitutional Court}

The work of legal assistants can be described as a "black box": participants in disputes as well as interested lay people cannot observe the process. Using a market metaphor, the Court frames the relationship between disputant parties as one that has to be "satisfied through the symbolic exchange of institutional "goods" (judgments, decisions, and others)" (Massing 2002, p. 209). Though we may not be able to observe how the formulation of legal positions creates meaning, we can observe the circulation of documents, which are the material form of symbolic goods produced in the Court. Therefore, we can analyze the trajectory of the case by studying the production of different types of documents and their reallocation.

There are several strategies that might be employed in tracking the trajectory of any given case. One such strategy is to track an individual case from the moment when the petitioner files with the Court to the implementation of a final decision on the case. However, due to the constraints of our data, we have opted for a different strategy that investigates why and how a large number of petitions leads to such a small number of decisions as shown in Figure 2. 


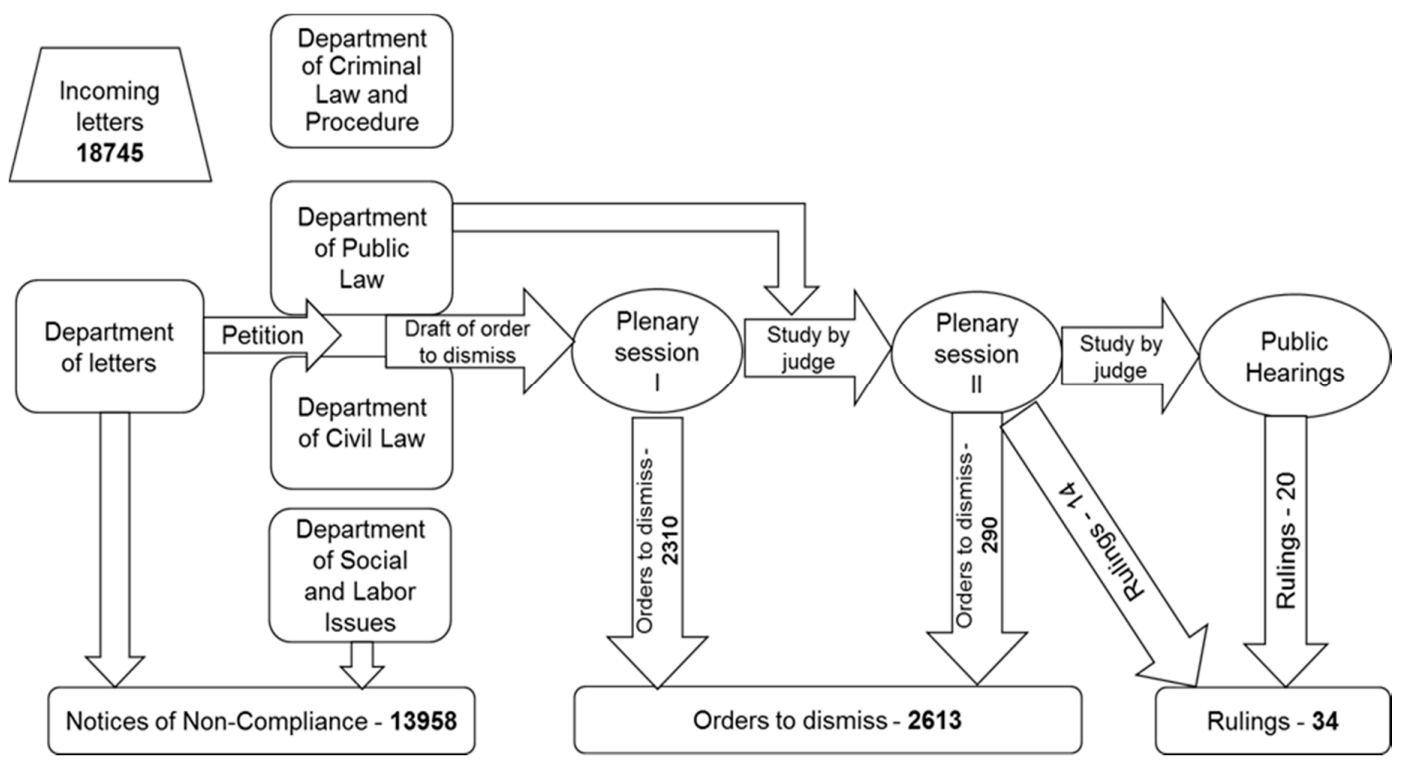

Figure 2. The petition flow in the Constitutional Court

What does it take for a petition to have a successful trajectory through the bureaucracy of the Constitutional Court? From the petitioner's point of view, the success of a complaint means that it has reached oral arguments, which end with the decision on merit (in Russian, "postanovlenie"). However, this view of the Court's decision is oversimplified. Every type of court decision, including all the forms of written communication with the petitioner, generates outcomes that affect the petitioner. The complaint might never be viewed as being resolved in a simplistically conceived victory or failure, but needs to be examined as reaching a more nuanced resolution within different stages of the Court's bureaucracy.

The trajectory of a successful petition consists of eight stages. The advancement of an average petition might be interrupted in its first, third, or sixth stages. These crucial points correspond with the change of status of documents (notices and decisions) issued by the Court at each stage.

During the first stage, the clerks of the Correspondence Department analyze all incoming mail. The staff of the Correspondence Department consists largely of junior lawyers whose task is not only to catalogue and digitize the incoming mail but also to sort the mail out. They do a preliminary analysis of the mail and eliminate those petitions deemed completely non-compliant, namely petitions that do not satisfy the basic requirements of Article 37 of the LCC. Upon first review, the clerks of the Correspondence Department notify petitioners and explain the reasoning behind decisions to deny their petition. The clerks of the Correspondence Department admit, however, that their primary task is:

to minimize the number of interaction with complainants. Therefore, we try to explain in detail the reasons for denying the petition.

(Interview 1)

The Notice of Non-Compliance (in Russian, "uvedomlenie o nesootvetstvii") issued by the Correspondence Department is a simple document composed from a standard template in which the Court accounts for why the petition was deemed non-compliant. The notice is usually supplemented by an excerpt from Article 37 of the LCC containing the requirements for a petition to be considered by the RCC. The notice is designed to help lay people understand the vague and often incomprehensible wording of the LCC.

If the Correspondence Department clerks determine that a petition satisfies the basic legal requirements, they transfer it to the second stage, the legal departments. At this stage, the legal assistants of the four legal departments analyze the petition and decide whether the issues discussed 
in it fall within the jurisdiction of the Constitutional Court. If the petition is not relevant and does not satisfy the requirements of LCC, the petitioner receives a rejection notice of non-compliance produced by the legal assistants of the legal departments. In our research, it was not possible to determine how many notices were issued by the Correspondence Department and how many were issued by the four legal departments. The Court sent a total of 13,958 Notices of Non-Compliance in 2012 alone. The majority of petitioners who receive the notice of non-compliance do not appeal. In 2012, the number of non-appealed petitions was 8100 , which amounted to roughly $43 \%$ of all the petitions received by the Court. The reluctance to appeal the Court's denial may be explained by the low level of legal competence among petitioners and by the lack of access to legal services.

Even though we are unable to ascertain their exact distribution, the question of which department sends out a non-compliance notice does make a difference to the litigants involved. While the clerks at the Correspondence Department send a highly standardized notice, created from a uniform template approved by the department head, the legal assistants have more room for explaining the rationale governing the denial of a given petition. For example, they use their own set of templates created over a period of time and catered to the demands of their practice. They also write more personalized notices in which the legal assistant might even advise the petitioner on how to improve the petition so that it might pass the filters of the Secretariat. In contrast to the notices sent by the Correspondence Department, which only explain the formal legal requirements not satisfied by a petition (for instance, a missing fee), legal assistants signal how the content of a petition can be improved.

Our work has a twofold goal: on the one hand, we have to protect the Court from unfounded complaints, on the other hand, we have to assist a petitioner to fully implement their right to apply to the Constitutional Court. Not every petitioner can hire a personal lawyer. Therefore, in our notices we aim to help improve the petitions so that, in the next iteration, it might be possible to advance it to the judges.

(Interview 6)

Let's say, in our notices we start by listing the formal shortcomings of the complaint. But towards the end we might provide some suggestions on how to improve the petition. For example, we might advise [them] to study decisions made by the Court earlier [that could lead them], potentially, to reassess their own chances to get judicial review or to improve the petition.

(Interview 8)

It is also necessary to distinguish a petition from a complaint. Not every petition to the Constitutional Court can become a complaint. Only those that satisfy the formal requirements and that contain questions falling within the jurisdiction of the Constitutional Court can become a complaint. Complaints present a subset of cases in which the constitutionality of a federal or local statute is drawn into question. This step - the transformation of an ordinary petition to a complaint to the Constitutional Court-is the task of the legal assistants of the four legal departments. The transformation of the petition into a complaint is executed during the third stage. Only in this stage do the judges get involved in the decision making process since they are authorized to deal only with complaints. All the work done beforehand by the Secretariat prepares the petition for the Court's consideration.

In this stage, the trajectory of the petition can veer off into one of two different directions. The first, step 3a: in case the question is irrelevant, or relevant but trivial, or has been already been solved by the court some time before, the legal assistants of the legal departments prepare a draft of the order to dismiss the complaint (in Russian, "opredelenie ob otkaze"). The main duty of the legal assistants of the Secretariat at this stage is to study the complaint in detail and also to prepare a draft of the order to dismiss the complaint. This draft is prepared in cases when the legal assistant finds that the complaint falls short of demonstrating that the contested legal norm violates the constitutional 
rights of the litigant, or, again, if the Court has already formulated its legal position on the issue in a previous decision.

The order to dismiss the complaint is a document in which the Court explains the reasons for the decision not to consider the case on merit. With this decision, the Court offers an interpretation and explanation of its legal positions, and estimates the constitutionality of contested legal norms. The litigants often seek this interpretation because it clarifies the law and its application for specific cases. However, the order to dismiss the complaint at this stage is usually very short and very simple, containing some references to past decisions made by the Court on similar issues.

The second, step $3 b$ : in case the question is relevant to the consideration of constitutional law and non-trivial, the legal advisers write a closing summary on the complaint (in Russian, "zakliuchenie"). This summary is directly submitted to the Court. The decision to write a closing summary about the complaint is made only if the legal adviser is convinced that the contested legal norm actually violates the constitutional rights of the petitioner. The decision concerning which cases are rejected, and which are allowed to proceed to the next stage, is based on the legal adviser's expertise, but also on their attitudes, and values. However, this decision is not taken by the legal adviser alone. The heads of all the legal departments and the heads of the Secretariat gather twice a month to discuss complaints that will be submitted to the Court.

Legal assistants never make the decision to advance the case to the judges by themselves. Each prospective petition is first discussed in a meeting with the head of the legal department and other colleagues. In monthly meetings, the heads of all four legal departments and the head and vice-head of the Secretariat discuss all cases that are supposed to proceed to the judges.

The number of petitions that advanced past the third stage in 2012 was 2613 (14\%). From the statistical data available, it is difficult to distinguish which cases proceeded through venue $3 \mathrm{a}$ and which proceeded through venue $3 \mathrm{~b}$. We can rely only on indirect evidence, namely the date on which the decision was issued, and whether the case had been studied by a particular judge before being advanced to the Court for consideration. From this indirect evidence, we can estimate that the legal advisers prepared drafts of orders to dismiss approximately 2300 complaints. About 290 of the complaints were sent to the Court with the closing summary of the Secretariat.

Thus, at this stage, the work of the Secretariat is finished and the decision making process becomes the responsibility of the nineteen judges of the Court.

During the fourth step, drafts of the order to dismiss are distributed among the judges. These drafts, prepared by the legal departments, are normally received by the judges a week prior to the plenary session. The judges study complaints and drafts of dismissal orders, commenting on cases they are interested in. The judges tend to be selective in the amount of attention they pay to each case. They pay more attention to cases in their area of expertise, treating the rest cursorily. Even then, only cases with some peculiarity or importance to a particular judge are studied with care. While conducting interviews in judges' offices, we observed a certain number of select cases (usually between three and ten) being flagged with a green sticker, which means that the judge finds these cases deserving of special attention. Taking into account the diversity of expertise among the nineteen judges, we can surmise that, on average, 30 to 40 out of approximately 200 cases are normally found deserving of the judges' attention.

During the plenary session, the Head of each department presents those cases which have been marked by the judges as important, at which point the judges start to discuss them openly. In most cases, the judges approve the drafts of the order to dismiss, but sometimes they decide to grant the case a deeper level of legal study. Given their high caseload, judges are typically reluctant to select cases in their dockets. It is may be the case that some judges are more active in defending cases for future investigation, but the case selection process is too secretive to ascertain this. Usually very few cases cause intense debate among the justices: no more than one to three out of approximately 150-180 cases considered at the plenary session. If the majority of judges vote for deeper research into the case, the President of the Court appoints one of the judges to take it on for further consideration. 
If we look at the process of case selection from a historical perspective (Table 1), we can see that more petitions have been avanced to judges in recent years. This illustrates the fact that the responsibility for the selection of the cases and for forming the agenda of the Russian Constitutional Court is allocated more to the judges and less to the legal advisers of the Secretariat. The number of cases that were presented to judges in the form of drafts of dismissal orders nearly doubled in 2009, compared to 2008, and has been steadily growing ever since (Figure 1). Thus, the burden of the selection process has shifted disproportionately from the second to the fourth stage. This shift can be explained, at least partially, by the replacement of significant numbers of the Secretariat staff during the transfer of the Court from Moscow to St. Petersburg. The other possible explanation is the rising quality of the petitions: petitions that cannot simply be found to be non-compliant with the LCC. While these changes, one might think, should have benefited the petitioners as their chances to receive a day in court increased, it has not, unfortunately, been the case, and the final outcome of the RCC selection process has not radically changed: very few cases reach the stage of oral argument that might result in a final ruling (in Russian, "postanovlenie").

During the fifth stage, the judges begin to study complaints they have received from the Secretariat (each in the form of a closing summary prepared at step 3b) or cases the Court found to be deserving of further consideration after the plenary session. This work is undergone independently of everything the staff of the legal departments worked on during the previous stages. Each judge develops their own strategy for dealing with the cases they have received for legal analysis. Some judges actively start their own legal inquiry and send dozens of requests, seeking expert advice from, say, government bodies and/or university legal scholars. Some judges are satisfied by the closing summary prepared by the Secretariat and base their decision mainly on their opinion. In each legal department there is at least one senior legal assistant who works primarily on closing summaries on judge's assignment. Other judges prefer to discuss the intricate points of the case with their personal assistants or with the legal assistants of the Secretariat. However, this last possibility happens quite rarely, as the communication between legal departments and judges is generally restricted to written communication and document exchange.

During the sixth stage, called the "plenary session on the judges' report", the judges gather again to make a decision on whether the complaints should be dismissed by the Court. Each judge presents drafts of the order to dismiss, following their study of the case. The orders issued at this stage to dismiss complaints contain well-grounded interpretations of contested norms and advise law enforcement agencies how they should apply the norms properly.

Before 2011, the Court sometimes released a dismissal order with a positive outcome. This type of decision was similar to an actual ruling (or decision on merit) and contained instructions to the lower court to revise its decision, but not requiring, however, that any amendments be made to the contested legal norm. With the amendments made to LCC in 2011, these types of decisions, with positive outcome, have almost disappeared.

Also at this stage, the dissenting opinions of those judges who disagree with the decision regularly supplement the denial of complaint to the Court. In this supplement, the judges who opposed the decision either state their disagreement with the denial of the complaint, or propose an alternative interpretation of the legal norms underlying the denial.

If it is decided that the case should proceed to the highest level of consideration by the judges, (i.e., the open court hearings or "oral arguments"), the reporting judge, appointed by the President of the Court on the basis of the judge's area of expertise and current workload, continues to study the case and becomes responsible for its public presentation during public hearings.

The seventh stage - the public hearing - is the only procedural step fully accessible to the public. Everyone can attend these, and videos of the most salient cases can also be found online.

Finally, at the eighth stage, the Court issues its ruling (in Russian, "postanovlenie"). Normally it takes the Court from one to three months to make a final decision. But the process of reaching that decision is not easy. Towards the end of that process, the judges hold several additional meetings before the decision is actually finalized. The reporting judge is responsible for writing the ruling 
following the decision on the merit made by the Court. Only the rulings of the Court can assert whether a contested legal norm is fully or partially unconstitutional.

Our study of the trajectory of a petition to the Constitutional Court shows that the majority of petitions never leaves the Secretariat, never proceeding to the judges. To begin with, the remarkably high number of Notices on Non-Compliance is worth investigating. These numbers raise a range of questions. What can best explain the Secretariat's practice? Is the Secretariat too active in filtering out petitions? How does the Court coordinate with the work of the Secretariat?

\section{Discussion of the Case Selection Procedure at the Constitutional Court}

The primary goal addressed in the petition to the Constitutional Court during the decision-making process is "to make a choice between conflicting rights and to correct the evolving social imbalance" (Massing 2002). Thus, the case selection process as a part of a broader decision-making process reflects the Court's effectiveness in solving this imbalance.

Hereafter, I will concentrate only on the work of the Secretariat, as it is the place where the flow of featureless petitions is given shape and the structure of those allowed to move forward transform into individual complaints. An explanation of what a legal assistant's job is and what their duty and responsibilities are might further illuminate the process. It is necessary to account for the degree of their mutual structural dependence (or independence) and the degree to which their activity is controlled by the judges.

There are at least three hypotheses that may help explain the case selection process within the Russian Constitutional Court. These hypotheses are not mutually exclusive and all of them can be used to describe the process of case selection by the Secretariat. The first postulates that the decision concerning what case should advance forward is based solely on the requirements of Constitutional Court Law. I term this explanation a "legalistic" (or "jurisprudential") model. The second hypothesis concerns legal assistants making decisions based on their individual preferences and attitudes in selecting cases with a wide degree of discretion. The third hypothesis assumes that, like any other organization, the RCC has developed its own set of bureaucratic practices governing the case selection process. Such a bureaucratization (or managerialization) risks to undermine its role as a powerful political institution.

\section{The Jurisprudential Model}

The first of the above hypotheses is legalistic (jurisprudential). It explains the decision-making process purely from the legal point of view. This model states that only law guides the behavior of clerks and judges. When the court loses its capability to perform its political function soundly, it will concentrate on legal goals, namely definiteness and consistency (Baum and Perry 1993, p. 446). The focus on purely legalistic considerations helps the Court to overcome political partisanship because the secrecy of case selection proceedings "provides an easy way for the Court to decline involvement in politically volatile disputes" (Baum and Perry 1993, p. 446).

With regard to the case selection process at the RCC, this explanation seems the most sound. In all our interviews, legal assistants and judges insisted that the case selection is decided purely from legal standpoint. According to them, only cases that fully satisfy all the formal requirements of the Constitutional Court Law have a procedural future. Despite this being the most popular justification for the case selection process inside the Court, these principles, in our view, are not always adhered to strictly.

Indeed, the actual behavior of legal assistants allows more room for nuance and discretion. Not all the cases that might be good candidates for denial by the Correspondence Department are eliminated in practice. For example, the LCC requires that all petitions be presented in three copies, and that they contain a proof of fee payment and a copy of the legal act being contested in the petition. However, the absence of any one of these documents does not usually kill the petition right away. 
There is a decision, made by the governing body of the Court, that we should not contest minor formal non-compliance with the LCC. In many cases we can apply the requirements of LCC formally and refuse the petition on the ground of the absence of postal address of Gosudarstvennaya Duma (Russian Parliament). In this case, the petition will definitely come back, but the petitioner will be disgruntled with our formalism.

(Interview 24)

Thus, the Secretariat and the Court in general understand that some of the rules of the LCC are excessively formal and might even be perceived as tediously so. As a result, they are able to relax the formal requirements to a small extent and concentrate on the content of the petition. If the petition contains a clearly stated legal problem it is very likely to be sent on to the next stage. This happens quite regularly and therefore undermines the legalistic hypothesis concerning the case selection process.

\section{Discretion in Case Selection}

Lipsky was one of the first scholars to emphasize the considerable discretion state employees use in providing their day-to-day services (Lipsky 2010). He pointed out that professionals are "expected to exercise discretionary judgment in their field. They are regularly deferred to in their specialized areas of work and are relatively free from supervision by superiors or scrutiny by clients" (Lipsky 2010, p. 14). This statement can be applied to the clerkship of the Russian Constitutional Court. However, the Court itself is an elite political body that is involved in the creation of state policy, unlike mid-level bureaucracy that is supposed to implement rules and regulations shaped by policy-making elites (Segal and Spaeth 2002). Thus, legal assistants have a double burden: not only do they have to make a legally "correct" decision, but they must also realize the goals of the Court as a political institution.

The degree of influence the legal assistant has on the case selection process is highly debatable. The general public very often takes the view that this influence is relatively high.

It is indeed impossible to ignore the influence of legal assistants of the Secretariat, as they perform much of the legal work inside the Court. They select cases that are found non-compliant; they prepare drafts of dismissal orders; and they even prepare closing summaries for the complaint should the Court decide to accept it for consideration. With this amount of work being done by the Secretariat, it would be unwise to claim that the Secretariat does not hold any power over the judges.

A: We all debate whether the petition needs to be advanced to the judges or whether a draft of a dismissal order needs to be prepared. And of course, sometimes we have concurrent opinions. While one colleague might claim that nothing needs to be considered by the judges, another might insist that the question raised in the petition must be relayed to the judge because there is a constitutional problem. It is not an arbitrary decision; we make it collectively.

Q: And if there is fundamental disagreement on whether to advance the case to the judges, what do you do?

A: Nothing, we pass to the judge the summary of the case supplemented with the other department's position. Then the judge considers the entire summary, concurring positions and chooses the one they think is appropriate to this particular case and then starts preparing the report.

(Interview 17)

The question is how much power does the Secretariat really hold, and are there mechanisms in place that the Court can use to regulate this power? Which cases are chosen for the judges' consideration, and which cases are left behind? We can assume that judges send some signals to legal assistants based on their attitudes, which help, in turn, to determine which cases are selected and 
advanced to stage six (when the cases are studied by the judges) at least. However, the structure of the RCC, which allows a relatively large degree of independence and separation between the legal departments and the Court itself, does not seem conducive to sustaining an open communication channel in both directions.

However, if we look at the two divisions of RCC as two separate entities-the Secretariat and the Court itself-we will find that each member of the Secretariat interprets the law according to their own set of beliefs and attitudes. These beliefs push legal assistants to write a convincing closing summary of the complaint in order to render its arguments sound and persuasive. With the closing summary, the legal assistant first needs to persuade the Head of the Secretariat that the complaint deserves to proceed to the judges, and, second, they need to persuade the Court to take the complaint up for consideration. Sometimes, when they review particularly complicated cases, legal assistants write competing closing statements, staging a kind of contest amongst themselves. This is not an exceptional situation and in the event that both summaries are worthy of the judges' consideration, it is their duty, despite the quality of both, to choose the most convincing summary, or to propose an alternative solution.

Thus, it is necessary to reconstruct the attributes of a "good complaint," one that has a good procedural prospect in the eyes of the legal assistants of the Secretariat.

The first such attribute is the novelty of the question raised in the petition. Review is more often granted to cases that raise questions never addressed before. Most of these cases pop up when new legislation is introduced by the government, leading to a contradictory practice in the application of the law. The most remarkable event of this type was the introduction of the new Pension Law in 2003, which inspired so much controversy that hundreds petitioned the Court. Some other reforms have also brought a lot of attention to the Court from petitioners. In such cases, the Court makes decisions clarifying the ways in which the law should be applied. The Court's rulings and orders to dismiss are intended to provide public and lower courts with a better understanding of how the new legislation should be applied. This is how the Court creates precedent and how it frames legal policy. Both the legal assistants of the Secretariat and the judges maintain that in most cases involving new legislation, the petitions are examined very closely and thoroughly. Several petitions on the same topic, however, are often consolidated into one case and are decided jointly.

It is harder to find novelty in cases that call into question long-established laws but that instead focus on application of the law to a specific group of litigants. Still, even then petitioners have a good chance that their petition will be considered by the Court. However, the petitioners need to keep in mind that the court values legal research on whether the issue the petition addresses has been already adjudicated by the Court.

Before submitting an application to the Constitutional Court I studied all the decisions, all the implementations of this legal norm by the Supreme Court of the Russian Federation. I also studied the decisions of the Constitutional Court and found out that the Court had never made decisions on this particular question. From the very beginning I understood that this question had never been raised before the Court from this particular perspective.

(Interview 3)

The second attribute of a "good complaint" relies on the discretion of the legal assistants with regard to the logical consistency of the petition. In more than $90 \%$ of the cases, the petitions to the RCC are written by citizens themselves. Only about $4.4 \%$ of petitioners are able to hire a legal representative to present their case before the Constitutional Court. Therefore, petitions often appear awkward, convoluted, and logically incoherent. The duty of the legal assistant is to establish which norm is contested and how it violates the petitioner's constitutional rights. 
We are bound by these two questions, but why the petitioner thinks the legal act violates their rights, is not important to us. At the end, we need to find proper [legal] arguments.

(Interview 12)

The question of violation of rights is a tricky one. The legal assistant is supposed to play a two-stage game. First, they have to evaluate whether the contested norm is relevant to the question raised by the citizen in the petition. For instance, the petitioner (say, a parent of a college student) contests the Law on Education, which is not relevant to their rights, but is relevant to the rights of their child and, therefore, only the child is authorized to contest the law. Second, if the question is relevant, the legal assistant has to evaluate whether the contested norm violates the constitutional rights of the petitioner.

It would be again unwise to ignore the selection bias that is often informed by individual values. Thus, legal assistants allegedly put a greater level of effort into cases they find important, and skip cases that they find less important or trivial.

A: You know, there are no specific requirements regarding the closing summary on the petition. One might apply the general logic of the legal process. This means that a good document is one that accomplishes its goals. If I go to court (regular civil court) my claim should be written in such a way that the judge could cut out the title "Statement of claim" and write instead "Decision of the Court" and use all my arguments in my favor. The same logic works here. Naturally, when submitting the case material to judges we want to be as clear and detailed as possible. We try to conduct a deep legal study of the case in order to create a transparent and understandable summary.

Q: Is this a big document?

A: Normally, it's more than 10 pages but fewer than 25 .

(Interview 6)

The third attribute of a potentially successful petition is the type of petitioner who wrote it. Yet gauging its efficiency and practicality is a very controversial issue. The majority of petitions to the Constitutional Court are submitted by citizens themselves. For example, in 2012 the percentage of such petitions was $93.2 \%$; another $4.4 \%$ of the petitions were prepared by a legal representative of the litigant; only $1.7 \%$ of the petitioners were business entities; and only a few petitions were submitted by governmental or legislative bodies or by non-commercial organizations. The success rate, however, differs significantly: of the 18,745 of the petitions submitted by citizens in 2012, only 27 ended with a decision on the merit. Some of the petitions were consolidated into one case; therefore, the total number of actual rulings was only seven (with a success rate of $0.04 \%$ ). The petitions submitted by the federal and regional legislative bodies give us a different picture altogether. Of the fifteen requests submitted by these entities, the Court made decisions on ten and issued five rulings (with a success rate of 33\%). The reasons behind these differences require special study. However, everyone in the Court is aware of these numbers and, so, the Secretariat uses the type of petitioner as an indicator of what kinds of petitions need to be advanced. Nevertheless, the legal assistants will hardly ever admit that they treat the petitions submitted by the legislative bodies any differently than those submitted by private individuals. They would rather explain these unusual inequalities where selectiveness is concerned from a legislative perspective: the requests of legislative bodies can be sent directly to the Constitutional Court while the decisions of lower courts with lesser jurisdiction are a necessary prerequisite for citizens' petitions to be considered by the Court.

The fourth factor that might drive the success of a petition is whether the petition raises a problem often discussed in legal scholarship. Many of the legal assistants in the Secretariat have an academic background. Most of them, besides having graduate degrees in Law, regularly publish in legal journals and teach in the legal departments of different universities in St. Petersburg. That is why they are advanced in legal theory and skilled in legal discussion: 
When there is a problem in legal theory and we know about that problem, the petition is immediately distributed to the most experienced legal assistant to prepare the closing summary and send it to the judges.

(Interview 21)

Legal assistants find this situation very attractive and challenging:

It is interesting to work on such complaints. There is room for originality, and such cases bring an opportunity to implement some scientific ideas. It is possible to execute the results of my study while writing the closing summary. However, I have to emphasize that the closing summaries differ considerably in style from the expert memo, which I wrote as a legal scholar before I started to work for the Court.

(Interview 8)

The political salience of the problem had not often been discussed by our respondents. The vast majority of the cases submitted to the Court deal with criminal and social issues. Therefore, most of the legal assistants have never considered petitions that target the most disputable laws, those laws which represent the gross violation of basic constitutional rights, such as the "Law of Freedom of Assembly"4, or other similar legislation.

While the legal assistants of the Secretariat unequivocally possess some degree of power over which case gets to proceed, their influence should not, though, be overestimated. The final decision is made during the plenary session by the judges themselves. The likelihood that a judge will accept the drafts written by the Secretariat's legal assistants depends on the issue posed in the petition. An individual judge can sometimes be more inclined to persuade his colleagues that the petition merits some review. There are several mechanisms that regulate the influence of the Secretariat over the case selection process. As a relatively big organization, the Court develops mechanisms of formal and informal control over the Secretariat.

First, there is a legal rule that gives a petitioner the right to demand the consideration of his petition by the Court which actually bypasses the Secretariat all together. This right is stated in art. 40 of the LCC (Balytnikov 2012) and in the art. 23 of the Rules of Court (Sivitskii 2012a). When they considered introducing this element to the LCC, the legislators likely presumed that petitioners might want an instrument to contain and limit the influence the Secretariat over the case selection process. There are sometimes petitioners who utilize this right. Nevertheless, none of the Court workers we interviewed were able to recall an example where this type of petition was given consideration on merit and was denied by the judges during the plenary sessions.

The flow of written memos documenting the judges' directives to the Secretariat is the second mechanism to manage the case selection process occurring in the Secretariat. In general, the workers of the Secretariat, with the exception of the heads of the legal departments, do not attend plenary sessions. Therefore, the most valuable sources of information about the judges' attitudes and propensities in the case selection process are the transcripts of the plenary sessions. While reading a judge's discussion about particular cases, the legal assistants receive information, clues as to how to prepare drafts of the order to dismiss, which arguments can be legitimately used to ground the drafts of the decision to dismiss, and how the drafts should be developed in terms of writing and style.

Plenary session transcripts are not available to legal assistants. Only the judges' most important remarks regarding the case selection process and their instructions to the Secretariat are transmitted in the form of written directives via the head of the Secretariat.

4 In 2012, the law amending the Administrative code introduced draconian fines for violating rules on holding public events and imposed various other restrictions that made it more difficult and costly for those opposed to government policies to engage in public protests. The Constitutional Court attacked some provisions of the law in its decision from 14 February 2013. 
The power of the legal assistants over the judges in the case selection process is not unlimited. Before the plenary session, each judge receives all the drafts of the orders to dismiss prepared by the legal assistants of the Secretariat and they have a week to study them. If the judges want to change something in a draft or they think that the case class for deeper consideration, they make a note, or a mark, indicating that the case must be discussed during the plenary session. Thus, judges are not excluded from the case selection process and can exercise complete control over the agenda of the Court.

While the Court uses different instruments to constrain the influence of the legal assistants, there remains a problem with the credibility of the Court's decisions. The fact that the drafts of the orders to dismiss are written by legal assistants regularly draws fire from lawyers and the general public.

A desire by the Secretariat to avoid the "excessive" activism of their critics may have resulted in some of the significant changes seen in case selection patterns. As it has been shown above (Figure 1), the number of the petitions found non-compliant in 2008 significantly decreased, while the numbers of court decisions to dismiss cases increased.

The increase in the numbers of the Orders to Dismiss can be easily explained. When we were in Moscow, the practice had evolved in a way that the petition was first answered by the legal assistants. If we estimated that there is no perspective to proceed the petition to the ruling, the legal department wrote an answer. And the legal assistants sometimes went too far while reasoning their answer, beyond their competence stated in art. 40 of LCC. For instance, they could mention in their notice that the petition was written by an inappropriate person, because it was undoubtedly to the legal assistant that the Court would issue the order to dismiss. So, at the expense of those responses, we reduced the number of the orders. Now we strictly adhere to the law, and will not get involved, even slightly, in the competence of the judges. We will strictly do only what the law allows us to do. And when we see here something where we used to write in the answer, but it should have been decided by judges, we prepare the draft of the order to dismiss instead of notice of the Secretariat.

(Interview 17)

There is not much comparative scholarship on the work of legal assistants in other courts. By comparing the case of the Russian Constitutional Court with that of the U.S. Supreme Court, we might be able to highlight differences in practice and better understand our findings. Since the late 1950s, the question of whether the clerks of the U.S. Supreme Court influence judges has popped up more or less regularly as a topic of socio-legal research ${ }^{5}$. While the way the question is often stated in legal literature presumes a scandalous answer, the studies conducted so far speculate that the influence of law clerks is lower than is assumed by the general public (Provine 1980; Peppers 2006; Kenney 2000; Ward and Weiden 2006). It is not different in the Russian Constitutional Court. The discretion and freedom of legal assistants are regulated by a set of formal rules and informal interaction between judges and the Secretariat via the heads of the four legal departments and the head of the Secretariat itself. However, the direct interaction between legal assistants of the Secretariat and judges is very limited and it occurs extremely rarely inside the court. In this sense the practices in the Russian Constitutional Court substantially differ from those in the U.S. Supreme Court.

\section{Managerialization of the Case Selection Process}

The discretion of legal assistants is constrained not only by the messages that the judges send to the Secretariat in the form of written testimonials and transcripts of the plenary sessions, but also

5 See historical references in (Peppers 2006). 
by the logic of a bureaucratic organization. This process of managerialization (or bureaucratization) is evidently observed in all the stages of court work. As Table 1 shows, the number of petitions that the Court receives annually has increased significantly over the past five years. While the court's capacity to reach a certain number of decisions is limited, the time and effectiveness of the case processing come into focus.

Some scholars state that, in response to the increased workload, the Court could start experimenting with various procedures in order to "alleviate the burden imposed upon the Court by lay-drafted petitions" (Provine 1980, p. 20). Others put forward political arguments. In their view, when courts fail to carry out their social and political role and are incapable of creating effective policies, the remedial agenda is all that is left. Instead of playing an active role in the adjudication of conflicts between different branches of power, the court should adopt a quasi-bureaucratic and quasi-legislative role. As Grossman and Epp (2002) write, judges incessantly belt out the refrain, "courts should be courts". However, with this devaluation of their role, "they weaken political process and imperil their own legitimacy" (Grossman and Epp 2002, p. 104).

The workload of legal assistants in the Constitutional Court is rather high. Each clerk working at the Correspondence Department is expected to run through and make a decision up to 10 to 20 petitions a day. The legal assistants who work in the legal departments, are not only expected to filter out petitions, but also to perform a legal investigation and to prepare drafts of the decisions to dismiss and memos for judges. The workload in terms of sheer quantity is very unequal between different legal departments, every week a legal assistant at the Department of Public Law sorts 3 to 4 cases. At the Department of Criminal Law, a legal assistant will often handle ten.

The process of bureaucratization (or managerialization) is taking place on several levels inside the Russian Constitutional Court. First, the court develops and complicates its own routines. Secondly, the court reinforces its own legitimacy by emphasizing the timing of case processing.

\subsection{Routines of the Court}

Because the Court deals with thousands of petitions annually, its tasks unavoidably become "routinized" (Nelson and Winter 1982). The routine is the set of rules, procedures, agreements, roles, strategies and technologies that constitute the organization (Lewitt and March 1995).

Cohendet and Llerena (2003) lay out the three functions of the routine: coordinational, cognitive, and motivational. The cognitive function of the routine is responsible for the translation of knowledge in the organization. The motivational function of the routine lies in the control of intra-organizational conflict. Organizations develop practices that improve the use of limited resources. The routine guarantees the regularity and predictability of individual behavior as a part of collective behavior because the routine embodies the pattern of a successful solution to a problem in the past.

The coordination function of the routine is performed through the use of templates, for instance, to prepare the notices of non-compliance and drafts of the orders to dismiss. These templates contain references to specific articles of legal acts or previously prepared statements explaining why the petition is found inappropriate. After legal assistants finish the study of the petition and make a decision on what to write in the response, they only need to combine different templates in one letter. The Secretariat explains the use of such templates by emphasizing the need to adhere to the principle of uniformity in its correspondence, thus coordinating the work of many people in order to achieve a consistent outcome.

If you let any person to write in her own way, the Court won't be a public entity anymore but the assembly of novelists. Here you go. And so yes, we start from the particular template. Especially because, well, it makes easier to check our answers. To keep the work in the mainstream. 
The templates and the electronic database of notices and orders also perform a cognitive function. Legal assistants can use them to refer to a solution found by a colleague on a similar question or in analogous case and thereby reduce the level of personal anxiety or uncertainty in the performance of their work.

The growth of the formalization through templates leads to a redistribution of control and decrease in the degree of personal responsibility. Each notice of non-compliance is subject to dual control, first by the filing legal assistant and second by the head of the department. The first reviews the formal elements of the notice, while the second checks the facts defined in the notice. Comprised from ordered templates, these standardized letters make their work faster and easier.

According to the evolutionary theory of the organization, the routinization of work procedures is a natural process following the growth of an organization (Nelson and Winter 1982). However, it leads to the loss of an individual approach to individual petitions.

Beforehand I tried to call a petitioner for a dialog, to give her a hint how to improve the petition. Now our work is totally templated...

(Interview 2)

Possible in a small organization, "soft" practices permit a high level of individualization and creativity in problem solution. They rarely survive in a big organization though. Quite naturally the degree of routinization is higher in places with a higher workload, i.e., in the Correspondence Department. However, it decreases as the petition progresses further to the latter stages of the decision-making process. In law departments, legal assistants are not constrained by templates imposed by their department or by court regulations. Rather, they develop their own templates. These templates allow them to ease their work and increase the speed with which they can write notices and drafts of order.

Organizational theorists state that elaborate routines are independent of individuals (Lewitt and March 1988). The routines are able to survive the constant change of the people who execute them. However, in the case of the Russian Constitutional Court, we observe the fundamental change of practices developed in the Court before its transfer to St. Petersburg. The transfer coincides with the replacement of a majority of the former legal assistants with new lawyers, and with the increase of the workload. Both the increase of the workload and the change of the court's staff resulted in the extinction of previously adopted "soft" routines. Though the practices that allowed a more individually oriented interaction with each petitioner, was replaced with the new, more stringent formalized rules.

\subsection{The Pressure of Time}

The time available for the consideration of the cases is one of the institutionalizing factors of the whole process of decision-making. The notion of reasonable litigation time is one of the basic principles of the judicial system. The delay in litigation causes a general dissatisfaction with the judicial system (Johnson 1997; Steelman 1997). Resnik (1982) wrote that in order to reduce the pressure of "calendar control", the judges should experiment with schemes that allow them to speed up the resolution of cases. The former President of the Russian Constitutional Court admitted that the pressure of time pushes the court to give wider authority to the Secretariat in order to control and better ensure the compliance of considered petitions to the LCC requirements (Vitruk 2010, p. 388).

In the Constitutional Court, the pressure of deadlines organizes the rhythm of both the judges and the entire Secretariat. The responsibilities of the legal assistants include the timing of response. The automatic record system sends a reminder of the approaching dead-line of case consideration. Moreover, it increased administrative control over the quality of public service and creates additional pressure on the Court's legal assistants. It all encourages the legal assistants to plan their work-flow very carefully and not to delay that work-flow.

The time of complaint consideration is limited to one month. If we (legal assistants at the Correspondence Department) see that the petition can be transferred to the legal 
department or to the analytical department, we seek to do this as soon as possible, at best in the same day, because they also need time to prepare an answer or the draft of the orders or the summary. As to the remaining petitions, we have more time to write the notices on non-compliance, but I personally intend not to postpone the work.

(Interview 1)

In order to economize the time and effort necessary to check the content of the drafts of the orders to dismiss prepared by the legal departments, the drafts are marked with colored stickers. The legal assistants use green stickers for the drafts of orders on questions which have been already addressed by the Court in its rulings or other orders. The red stickers are used to mark the cases that raise new questions.

The judges also have to work out strategies to manage the high workload and the constant increase of the number of complaints to be considered. While preparing for a plenary session, they distribute the drafts of the orders to dismiss among themselves and their two assistants. Thanks to the preparatory work leading to the selection of only those cases which contain important questions, the judges have an opportunity to save the time on discussion during the plenary session. After the introduction of new amendments to the LCC in 2011, and the abolishment of the two chambers, the amount of time spent on discussion became a topical problem. It is much more difficult to reach an agreement between nineteen judges than between nine (or ten) as it was in the two-chamber court. Though many of the studies on how the size of a jury affects the duration of a trial have been controversial, some of them have, more or less convincingly, shown that the average trial time for a jury of twelve would be twice as long as the trial time for a smaller jury (Zeisel and Diamond 1974). Similar logic is applicable to the work of the RCC judges.

Balancing the competing demands of time pressure and the need for a thorough analysis of the case is a difficult task. The Court's statistics show that the court generally fails to find this balance. In the last three years, the number of the orders to dismiss increased but the number of rulings remained stable (see Table 1). It means that the Secretariat has found the way to adapt to the increasing number of petitions, while the Court has floundered, unable to respond to the growth of its workload.

\section{Conclusions}

Over the last five years, the Russian Constitutional Court has experienced a lot of shock, each time undermining its usual work. Events, such as the transfer of the Court from Moscow to St. Petersburg and subsequent change of the legal personnel, the introduction of amendments to the LCC, and the increase in the number of petitions by about $20 \%$ in five years, have all influenced the case selection process.

There is no single explanation of the case selection process at the Constitutional Court. In the first stages of the process, we observe the significant influence of the Secretariat. Separated from the Court itself, the Secretariat and its legal assistants play a visible role in this process.

It would be a misconception to say that the LCC provides the legal assistants of the Secretariat with a strict guideline according to which cases have to be selected and others have to be dismissed. In the end, it is obvious that the rules are vague and the degree of freedom in the decision making process is relatively high.

The behavior of the legal assistants responsible for the filtering the petitions depends on different factors. In a court divided into two parts, legal assistants use their expertise to push forward to the judges the petitions they find most challenging. On the other hand, communication with petitioners has become much more formal and less individualized. Through this, the Secretariat curtails the pull of petitions. However, we do not find strong evidence that the Secretariat significantly influences the agenda of the Court. Instead, it is more likely that institutional and organizational factors have affected the way the Court forms its agenda. 
Acknowledgments: The author acknowledges the support of the Russian Science Foundation (Grant Number 14-18-02219), and is thankful to Vadim Volkov, Anssi Keinänen, Marina Kurkchian, Ella Paneyakh and anonymous reviewers for their help and critical comments.

Conflicts of Interest: The author declares no conflict of interest.

\section{References}

Aranovskii, Konstantin V., and Sergei D. Kniazev. 2012. Eshche raz o pismennom otpravlenii konstitutsionnogo pravosudia v Rossiiskoi Federatsii (Once Again about the Written Procedure in the Constitutional Court). Zhurnal Konstitutcionnogo Pravosudiia 4: 8-15.

Avak'ian, Suren A. 2011. Konstitutsionnyi Sud Rossiiskoi Federatcii: Neodnoznachnye zakonodatelnye novelly (The Constitutional Court of the Russian Federation: Ambiguous Legislative Novels). Konstitutsionnoe $i$ Munitsipalnoe Pravo 1: 3-7.

Avtonomov, Alexei S. 2009. Sekretariat Konstitutcionnogo Suda v Rossii: filtr dlia otseivaniia neobosnovannykh zhalob ili tormoz konstitutcionnogo pravosudiia (The Secretariat of the Constitutional Court in the Russia: A Filter to Sift out Noncompliant Petitions or the Brake of the Constitutional Justice). Zhurnal konstitutcionnogo pravosudiia 5: 26-30.

Balutenko, Maxim S., Grigorii V. Belonuchkin, and Konstantin A. Katanian. 1997. Konstitutcionnyi sud Rossii_Spravochnik (Russian Constitutional Court_Handbook). Edited by K. A. Katanian. Moscow: Panorama, p. 384.

Balytnikov, Vaidm V. 2012. St. 40. Rassmotrenie obrashchenii Sekretariatom Konstitutcionnogo Suda Rossiiskoi Federatsii (Art. 40. The Consideration of the Petitions by the Secretariat of the Constitutional Court of the Russian Federation). In Commentaries to the Federal Constitutional Act "On the Constitutional Court of the Russian Federation". Edited by Gadis A. Gadzhiev. Moscow: Norma, pp. 240-43.

Baum, Lawrence, and H. W. Perry. 1993. Case Selection and Decisionmaking in the U.S. Supreme Court. Law E Society Review 27: 443-59.

Baum, Lawrence. 1999. Comments delivered at Midwest Political Science Association. In Wasby, Stephen L. 2008. Clerking for an Appellate Judge: A Close Look. Seton Hall Circuit Review 5: 20-97.

Blokhin, Pavel. D. 2012. Deiatelnost sekretariata Konstitutcionnogo Suda Rossiiskoi Federatcii po rassmotreniiu zhalob grazhdan i ikh ob'edinenii: problemy kompetentsii (The Activity of the Constitutional Court of the Russian Federation in the Consideration of the Citizens' and their Unions' Petitions: The Question of the Competence). Zhurnal Konstitutcionnogo Pravosudiia 1: 14-22.

Cohendet, Patrick, and Patrick Llerena. 2003. Routines and the Theory of the Firm: The Role of Communities. Industrial and Corporate Change 12: 271-97. [CrossRef]

DiMaggio, Paul J., and Walter W. Powell. 1991. Introduction. In The New Institutionalism in Organizational Analysis. Chicago: University of Chicago Press, pp. 1-39.

Epstein, Lee, Jack Knight, and Olga Shvetsova. 2001. The Role of Constitutional Courts in the Establishment and Maintenance of Democratic Systems of Government. Law \& Society Review 35: 117-64.

Gadzhiev, Gadis. A. 2012. Introduction. In Kommentarii k Federalnomu Konstitutcionnomu zakonu “O Konstitutcionnom Sude Rossiiskoi Federatsii" (Commentaries to the Federal Constitutional Act "On the Constitutional Court of the Russian Federation"). Edited by G. A. Gadzhiev. Moscow: Norma, pp. 11-23.

Gillman, Howard, and Cornell W. Clayton. 1999. Beyond Judicial Attitudes: Institutional Approaches to Supreme Court Decision-Making. In Supreme Court Decision-Making: New Institutionalist Approaches. Chicago: University of Chicago Press, pp. 1-14.

Grossman, Joel B., and Charles R. Epp. 2002. Agenda Formation on the Policy Active U.S. Supreme Court. In Constitutional Courts in Comparison: The U.S. Supreme Court and the German Federal Constitutional Court. Edited by R. Rogowski and T. Gawron. New York: Berghahn, pp. 103-24.

Johnson, Carrie E. 1997. Rocket Dockets: Reducing Delay in Federal Civil Litigation. California Law Review 85: 225-64. [CrossRef]

Kenney, Sally. J. 2000. Beyond Principals and Agents: Seeing Courts as Organizations by Comparing Referendaires at the European Court of Justice and Law Clerks at the U.S. Supreme Court. Comparative Political Studies 33: 593-625. [CrossRef] 
Koroteev, Kirill, and Sergei Golubok. 2007. Judgment of the Russian Constitutional Court on Supervisory Review in Civil Proceedings: Denial of Justice, Denial of Europe. Human Rights Law Review 7: 619-32. [CrossRef]

Kudriavtsev, Yurii V. 2010. Kommentarii. Stenogramma kruglogo stola "Federalnyi konstitutcionnyi zakon “O Konstitutcionnom Sude Rossiiskoi Federatsii": opyt primeneniia i perspektivy sovershenstvovaniia. K 15-letnemu iubileiu" (Comment delivered at the round table for the 15th anniversary of the Federal Constitutional Law "On the Constitutional Court of the Russian Federation": Experience of application and prospects for improvement. Transcript). Zhurnal Konstitutcionnogo Pravosudiia 1: 1-15.

Lewitt, Barbara, and James. G. March. 1988. Organizational Learning. American Review of Sociology 14: 319-40.

Lewitt, Barbara, and James. G. March. 1995. Chester I. Barnard and the Intelligence of Learning. In Organizational Theory: From Chester Barnard to the Present and Beyond. Edited by Oliver E. Williamson. New York: Oxford University Press, p. 268.

Lipsky, Michael. 2010. Street Level Bureaucracy, 30th Anniversary Edition ed. New York: Russel Sage Foundation, p. 300.

Massing, Otwin. 2002. The Legal Assistants at the German Federal Constitutional Court: A "Black Box" of Research? A Comment. In Constitutional Courts in Comparison: The U.S. Supreme Court and the German Federal Constitutional Court. New York and Oxford: Berghahn Books, pp. 209-18.

Nastashkin, A. 2002. Stena, ili legko li dostuchatsia do Konstitutcionnogo Suda (Wall or Is It Possible to Knock the Constitutional Court). Zakon i Pravo 8: 59-64.

Nelson, Richard R., and Sidney G. Winter. 1982. An Evolutionary Theory of Economic Change. Cambridge: Harvard University Press.

Olsen, Johan P., and James G. March. 2006. Elaborating the "New Institutionalism". In The Oxford Handbook of Political Institutions. Edited by R. A. W. Rhodes, S. A. Binder and B. A. Rockman. Oxford: Oxford University Press, pp. 3-20.

Peppers, Todd C. 2006. Courtiers of the Marble Palace: The Rise and Influence of the Supreme Court Law Clerk. Stanford: Stanford University Press.

Perry, H. W. 1991. Deciding to Decide: Agenda Setting in the United States Supreme Court. Cambridge: Harvard University Press.

Pikhoia, Rudolf G. 2002. Prezident i Sovety: Politiko-konstitutcionnyi krizis 1993 g. (President and Soviets: Political and Constitutional Crisis of 1993). In Kuda idet Rossiia? Edited by Tatiana I. Zaslavskaia. Moscow: MSSES, pp. 341-52.

Provine, Doris. M. 1980. Case Selection in the United Supreme Court. Chicago: University of Chicago Press, p. 214. Resnik, Judith. 1982. Managerial Judges. Harvard Law Review 96: 374-448.

Segal, Jeffrey, and Harold Spaeth. 2002. The Supreme Court and the Attitudinal Model Revisited. New York: Cambridge University Press.

Sivitskii, Vladimir. A. 2012a. O dinamike tipologii reshenii Konstitutcionnogo Suda Rossiiskoi Federatsii (On the Dynamics of the Decisions' Typology of the Russian Constitutional Court). Pravo 2: 57-73.

Sivitskii, Vladimir. A. 2012b. O nekotorykh aspektakh rassmotreniia obrashchenii v adres Konstitutcionnogo Suda Rossiiskoi Federatsii v predvaritelnom poriadke ego sekretariatom (On Some Aspects of the Preliminary Consideration of the Petition to the Constitutional Court). Zhurnal Konstitutcionnogo Pravosudiia 1: 23-28.

Steelman, David C. 1997. Have We What Learned About Court Delay Since the Late 1970s? The Justice System Journal 19: 145-66. [CrossRef]

Swanson, Rick A., and Stephen L. Wasby. 2008. Good Stewards: Law Clerk Influence in State High Courts. The Justice System Journal 29: 24-46.

Thorson, Carla. 2012. Politics, Judicial Review, and the Russian Constitutional Court. Oxford: Palgrave Macmillan.

Trochev, Alexei. 2008. Judging Russia: Constitutional Court in Russian Politics 1990-2006. Cambridge: Cambridge University Press, p. 371.

Tuzov, Nikolai A. 2010. Kommentarii. Stenogramma kruglogo stola “Federalnyi konstitutcionnyi zakon "O Konstitutcionnom Sude Rossiiskoi Federatsii": opyt primeneniia i perspektivy sovershenstvovaniia. K 15-letnemu iubileiu" (Comment delivered at the round table for the 15th anniversary of the Federal Constitutional Law "On the Constitutional Court of the Russian Federation": Experience of application and prospects for improvement. Transcript). Zhurnal Konstitutcionnogo Pravosudiia 1: 1-15.

Vitruk, Nikolai V. 2010. Konstitutcionnoe pravosudie. Sudebno-konstitutcionnoe pravo i process (Constitutional Justice. Constitutional Judicial Law and Procedure). Moscow: INFRA-M, p. 592. 
Ward, Artemus, and David L. Weiden. 2006. Sorcerers' Apprentices: 100 Years of Law Clerks in the United States Supreme Court. New York: New York University Press, p. 336.

Wasby, Stephen L. 2012. Clerking for an Appellate Judge: A Close Look. Seton Hall Circuit Review 5: $20-97$.

Zeisel, Hans, and Shari S. Diamond. 1974. "Convincing Empirical Evidence" on the Six Member Jury. The University of Chicago Law Review 41: 281-95. [CrossRef]

Zucker, Lynne G. 1987. Institutional Theories of Organization. Annual Review of Sociology 13: 443-64. [CrossRef] 